\title{
ALEXÂNIA E ABADIÂNIA, DUAS CIDADES NOVAS PARA BRASÍLIA*
}

Pedro Henrique Máximo Pereira

Ricardo Trevisan

Trabalho apresentado no $18^{\circ}$ ENANPUR, Natal, 2019.

\section{Resumo}

Brasília, a apoteose do Movimento Moderno, não se restringe a ela própria. Seu famoso projeto, sua complexa ocupação e sua inquestionável relevância urbano-arquitetônica se desdobraram noutros territórios urbanos do interior do Brasil, mesmo aqueles distantes de seu canteiro de obras. A partir destes pressupostos, apresentamos os casos de Alexânia (1957) e Abadiânia (1960-61), cidades novas e ainda inéditas na historiografia do urbanismo brasileiro. A vinculação destas cidades a Brasília é direta. Ambas foram planejadas, projetadas e ocupadas durante a construção da nova capital (1957-1960) e das rodovias Brasília-Anápolis (1957-58) e Belém-Brasília (1958-59), infraestrutura que as interligam. O projeto de Alexânia foi encomendado por Alex Abdallah à Empresa Brasil de Imóveis Limitada, numa ação empreendedora, e executada pelo engenheiro alemão Fritz Gezets, e Abadiânia foi projetada e implantada pelo agrimensor Nilton Rabello, sendo ela fruto de uma negociação iniciada em 1956 entre Oribes Gontijo, o prefeito da cidade, e Bernardo Sayão. Assim, vislumbramos uma contribuição histórica e teórica com estes fatos inéditos a partir desta pesquisa aqui relatada. Neste documento são expostos seus projetos e seus processos de ocupação.

Palavras-chave: Cidades Novas, Alexânia, Abadiânia, Rodovia Belém-Brasília, Brasília

\section{Abstract}

Brasilia, the apotheosis of the Modern Movement, is not restricted to itself. Its famous project, its complex occupation and its unquestionable urban-architectural relevance unfolded in other urban territories of the interior of Brazil, even those distant from his construction site. Based on these assumptions, we present the cases of Alexania (1957) and Abadiania (1960-61), new cities and unpublished in the historiography of Brazilian urbanism. The connection of these cities to Brasilia is direct. Both were planned, designed and occupied during the construction of the new capital (1957-1960) and the Brasília-Anápolis (1957-58) and Belém-Brasília (195859) highways, the infrastructure that interconnected them. The Alexania project was commissioned by Alex Abdallah from Empresa Brasil de Imóveis Limitada, in an entrepreneurial action, and executed by the German engineer Fritz Gezets, and Abadiania was designed and implemented by the surveyor Nilton Rabello, being the result of a negotiation begun in 1956 between Oribes Gontijo, the mayor of the city, and Bernardo Sayão. Thus, we glimpse a historical and theoretical contribution with these unpublished facts from this research reported here. In this document are exposed their projects and their processes of occupation.

Key-words: New Cities, Alexania, Abadiania, Belem-Brasilia Highway, Brasilia 


\section{INTRODUÇÃO}

A transferência da capital federal em 1960, do Rio de Janeiro para Brasília, marcou um intenso processo de deslocamento das forças produtivas, econômicas e demográficas para o centro do Brasil. É notório hoje, no próprio Distrito Federal e Entorno, por exemplo, as consequências positivas e negativas deste processo (população estimada em 2018 para a Região Metropolitana do Distrito Federal é de 4,5 milhões de habitantes ${ }^{1}$ ). Nestes últimos 60 anos, um fenômeno urbano provocado por Brasília assaltou as cidades ali preexistentes e incitou fortemente a criação daquelas que ainda não existiam. Houve uma espécie de reprodução dos feitos políticos federais nas localidades urbanas do centro-norte brasileiro e nas governanças locais e regionais. A partir de empreendedores urbanos ou de políticos ávidos a acompanharem o Zeitgeist nacional, um reordenamento do território nacional foi iniciado e preliminarmente implantado, fato silenciado por décadas e que neste trabalho pretendemos problematizar. Seria possível, neste sentido, avaliar ou mesmo medir os impactos de Brasília nos territórios urbanos do Planalto Central? Apresentamos para tal debate os casos das cidades goianas de Alexânia e Abadiânia. Ambas situam-se na BR-060 (antiga rodovia Brasília-Anápolis, parte do trajeto da rodovia Belém-Brasília) e possuem uma relação de proximidade com Brasília - 85 $\mathrm{km}$ e $115 \mathrm{~km}$ respectivamente. São cidades oriundas, assim como a nova capital, de processos de relocação de suas antigas sedes, portanto consideradas cidades novas, aquelas intencionalmente planejadas, projetadas, desenhadas e implantadas (TREVISAN, 2009).

Brasília, em política e projeto, direta ou indiretamente, fez emergir novos quadros técnicos, nomes outrora desconhecidos, cidades até então jamais vistas e imaginadas, saberes locais e universais, planos e desenhos que revelam soluções eruditas e populares para os ambientes urbanos, distantes daqueles mais desenvolvidos de nossa costa litorânea. Mais que encerrado em seu próprio desenho, o Plano Piloto de Brasília abriu as fronteiras do centro-norte à urbanização, à industrialização e o inseriu na lógica econômica que até então somente se reproduzia nas regiões mais ocupadas do país. Como pano de fundo, este artigo abarca outro problema: as críticas a Brasília e a seu processo de transferência. Ainda hoje os feitos em Brasília, os gastos dispendidos para executa-la e seu projeto urbanístico-arquitetônico são examinados e questionados. Ronaldo Couto (2001), em Brasilia Kubitschek de Oliveira, traz uma leitura crítica e às vezes ácida, irônica e controversa sobre a Capital. Suas críticas não são como as de James Holston (1993) em relação à cidade enquanto matéria e utopia. Couto discute seus aspectos históricos, econômicos e políticos e nos apresenta narrativas até então desconhecidas sobre os personagens envolvidos neste projeto nacional-desenvolvimentista. Ao abrir esta "Caixa de Pandora”, as leituras e interpretações dela
1 A Região Metropolitana do Distrito Federal é constituída, além do Distrito Federal, pelos municípios de: Abadiânia, Água Fria de Goiás, Águas Lindas de Goiás, Alexânia, Alto Paraíso de Goiás, Alvorada do Norte, Barro Alto, Cabeceiras, Cavalcante, $\mathrm{Ci}-$ dade Ocidental, Cocalzinho de Goiás, Corumbá de Goiás, Cristalina, Flores de Goiás, Formosa, Goianésia, Luziânia, Mimoso de Goiás, Niquelândia, Novo Gama, Padre Bernardo, Pirenópolis, Planaltina, Santo Antônio do Descoberto, São João d'Aliança, Simolândia, Valparaíso de Goiás, Vila Boa e Vila Propício, no estado de Goiás, e de Arinos, Buritis, Cabeceira Grande e Unaí, no estado de Minas Gerais. 
derivadas parecem encerrar a análise no Plano Piloto de Brasília e a acusa-lo de causa e efeito de uma artimanha política afeita à corrupção e a golpes de estado. Neste sentido, tais leituras desconsideram a multidimensionalidade e a transescalaridade dos fenômenos provocados por ele em todo o território nacional. Portanto, centrados no recorte acima apresentado dupla de cidades goianas -, dispomo-nos a enfrentar este problema, sobretudo a partir de sua dimensão urbana.

As médias e grandes cidades brasileiras, por vezes mais importantes nos quesitos demografia e economia que o vasto número de pequenas cidades que estão distribuídas pelo território nacional, ocupam privilegiados lugares na historiografia do urbanismo. Distante de ser uma observação negativa, apontamos, todavia, que há ainda um vasto campo a ser vasculhado, analisado e explicitado. Nessa esteira, revelaremos casos das consideradas "pequenas cidades". Não obstante e não menos importantes que casos de grande impacto, a constelação de pequenas cidades novas implantadas, como apontaremos adiante, foram estrategicamente criadas com vistas à ocupação do interior do Brasil, outrora lido como um imenso vazio na hinterlândia. Notadamente, apesar de pequenas, elas foram laboratórios urbanísticos de engenheiros, arquitetos, topógrafos, agrimensores, entre outros profissionais encarregados em projetá-las e materializá-las.

$\mathrm{Na}$ contextualização, por título Cidades Novas no percurso da Belém-Brasilia, apresentaremos uma miríade de casos de cidades criadas na curta duração da construção de Brasília (1956-1960), com recorte específico no trecho da rodovia Belém-Brasília implantada entre 1958 e 1959. Trata-se, portanto, de um recorte espaço-temporal que nos auxiliará a explicitar os impactos territoriais e urbanos nesta linha que rasga o Brasil do centro ao norte. Em seguida apontaremos os principais detalhes históricos e urbanísticos dos objetos selecionados para tal. De Olhos D'Água a Alexânia é o título da parte em que exporemos as contradições da relocação desta cidade, centrado na figura de Alex Abdallah, o promotor deste processo. Serão expostas as particularidades do desenho elaborado para Alexânia em 1957 pela Empresa Brasil de Imóveis Limitada e imediatamente executado pelo engenheiro Fritz Gezets, bem como a condução de sua ocupação inicial. Em De Posse D'Abadia a Abadiânia revelaremos os conflitos territoriais apresentados no processo de implantação do projeto para a nova cidade, projetada e executada pelo agrimensor Nilton Rabello em 1961, fruto de uma negociação que datava desde 1956 com Oribes Gontijo, o então prefeito do município. Duas cidades no contexto de fundação da nova capital; duas cidades novas para Brasília. Casos ainda se encontram inexistentes na historiografia do urbanismo brasileiro, portanto, vislumbramos uma contribuição histórica e teórica com estes fatos inéditos a partir desta pesquisa inédita.

Por fim, vale salientar que os critérios adotados para a elaboração deste trabalho derivam da contribuição teórica de 
Ricardo Trevisan (2009) para a classificação e consideração do que possa vir a ser uma cidade nova ${ }^{2}$. Ademais, tal trabalho é fruto de estudos direcionados aos projetos "Atlas de Cidades Novas do Brasil Republicano" e "Cronologia do Pensamento Urbanístico”.

\section{CIDADES NOVAS NO PERCURSO DA BELÉM-BRASÍLIA}

A transferência da capital federal para o interior do Brasil foi um evento historicamente importante para o desenvolvimento da nação como um todo. Tal fato, efetivamente ocorrido em 21 de abril de 1960 com a inauguração de Brasília, era ambicionado há no mínimo duzentos anos $^{3}$, contando, inclusive, com incursões prévias ao centro do país com vistas à escolha e delimitação de seu futuro sítio. Entretanto, sua mudança, ainda hoje, cerca de 60 anos depois de realizada, gera debates e críticas. Neste sentido, revisitar alguns de seus pontos é imprescindível.

O olhar contemporâneo para Brasília como capital do país, vale ressaltar, pressupõe considerações diversas para além de seu Plano Piloto. A complexidade que o território brasileiro adquiriu em função de tal mudança implica em críticas e leituras da mesma natureza, portanto aquelas que ocorrerem distantes disso cairão em simplificações. Algumas críticas, tais como aquelas de Vera Chaia e Miguel Chaia (2008), de certo modo, ignoram sua multidimensionalidade:

\begin{abstract}
A localização da cidade, sua concepção arquitetônica e o plano urbanístico são pistas que indicam vários tipos de isolamento, principalmente o geopolítico. Brasília é uma parte à parte do restante do país. Aliás, tais características antecipam sua funcionalidade para servir aos regimes autoritários como os que seguem ao golpe de 1964 . (CHAIA; CHAIA, 2008, p. 171)
\end{abstract}

Toda análise pressupõe recortes temáticos e teóricos, entretanto, ela não deve desconsiderar a multidimensionalidade dos universos, dos fatos e fenômenos que circunscrevem os eventos que perfilam seus objetos de pesquisa. $\mathrm{O}$ marco simbólico da mudança da capital federal não foi um fato isolado na história, mas deu continuidade às políticas de interiorização iniciadas ainda no Império, com o Plano de Ocupação da Capitania de Goyaz do século 18 e ao movimento Varguista (1930-1945) de ocupação e modernização da hinterlândia (Marcha para o Oeste). Não obstante, a própria crítica ao isolamento e a necessidade da implementação de políticas de ocupação, modernização e desenvolvimento do país revela sua fragilidade, ainda que distante da intencionalidade de tais autores. Ademais de tal posição, a transferência da capital nacional para Brasília faria cumprir a prerrogativa constitucional de interiorização dos poderes do Estado brasileiro.

A nova capital do Brasil no Planalto Central, estipulada pelo presidenciável Juscelino Kubitschek como objetivo síntese de seu Plano de Metas, carregaria a missão de integrar os quatro cantos

\footnotetext{
2 Para essa distinção, seis atributos lhes devem ser inescapáveis: 1) a presença de um profissional, 2) um local previamente selecionado, 3 ) um desejo pertinente à sua construção, 4) uma necessidade, 5) um projeto que satisfaça tecnicamente tal desejo, e 6) que ela materialize ou represente um tempo específico (TREVISAN, 2009, p. 87-88).

${ }^{3}$ A localização para uma nova capital na hinterlândia brasileira, como sabemos, antecedeu em muito o período JK (1955-1960), tendo sido especulada no período pombalino (1750-1780) e selecionada pela Missão Cruls entre 1892 e 1894. A Comissão Exploradora do Planalto Central criada pelo governo do Presidente Floriano Peixoto em 09 de junho de 1892, sendo chefiada pelo diretor do Observatório Nacional, Luiz Cruls, e composta por técnicos e cientistas diversos. O objetivo de tal Comissão era selecionar e demarcar a área do novo Distrito Federal na região central do país.
} 
da nação. As ações em prol desse desejo ocorreram imediatamente após a eleição de 1955 que o colocou no Palácio do Catete. Sua intenção era criar um cruzeiro de rodovias, grandes longitudinais cortadas por grandes transversais. No centro, seria localizada a sede dos poderes executivo, legislativo e judiciário do Brasil. Iniciado seu mandato em 1956, no mês de setembro Kubitschek criou a Companhia Urbanizadora da Nova Capital do Brasil (NOVACAP), definiu o nome da nova cidade como Brasília e delimitou o território do novo Distrito Federal (Lei no 2874 de 19 de setembro de 1956). Ausente de um planejamento regional e territorial prévio, como apontou Lucio Costa na ocasião do concurso para seu Plano Piloto (1991, p. 20), a partir de Brasília se desdobrariam planos e investimentos em infraestruturas de transportes (rodovias e aeroportos) e a implantação de redes técnicas (como usinas de produção de energia, redes de transmissão e centrais de distribuição) para, efetivamente, colocar o interior do Brasil no mapa.

Para a execução desse ambicioso plano de integração, a construção prévia de Brasília seria fundamental. Ela seria o ponto destino dos fluxos ao interior e de partida em direção às extremidades da nação (KUBITSCHEK, 2000, p. 84). No mês seguinte de tal institucionalização, em outubro de 1956, foi lançado o edital do concurso para o Plano Piloto de Brasília e a NOVACAP anunciava a imediata construção da estrada Anápolis-Brasilia, cujo objetivo era garantir o suprimento material para a execução da nova cidade. Foram dez empreiteiras responsáveis por realizar tal obra, cinco destinadas à abertura dos leitos de rodagem e respectivas pavimentação e as outras cinco destinadas à construção das onze pontes necessárias para vencer os $130 \mathrm{~km}$ que as separam. Sua finalização ocorreu em 30 de março de 1958, pouco mais de um ano do início das obras em maio 1957, à época, tempo recorde. Ainda em 1957, ligações com a região Sudeste foram iniciadas, como a rodovia Brasília-Belo Horizonte e Anápolis-Santos. A execução destas infraestruturas era de responsabilidade do Departamento Nacional de Estradas de Rodagem (DNER), empresa criada por Getúlio Vargas em 1937.

Com as obras iniciadas entre Anápolis (GO) e Santos (SP) faltava, para a concretização da primeira rodovia longitudinal do Brasil, um trecho de Brasília a Belém (PA). Ainda em 1957 obras que avançavam na direção ao Norte, partindo de Porangatu, foram iniciadas. A ideia da abertura de uma estrada de rodagem que atravessasse o país de norte a sul não era inédita, mas já pairava na governança brasileira desde a Era Vargas. A Transbrasiliana, como era nomeada esta infraestrutura no contexto do Governo Constitucional, em 1934 teve primeiro esboço a partir do Plano Geral de Viação Nacional (Decreto no 24.497 de 29/06/1934). Ela seria uma estrada de rodagem que teria aproximadamente $5.500 \mathrm{~km}$, interligando Belém (PA) a Livramento (RS). Iniciadas suas obras em 
Goiás em rotas fragmentadas, a coesão do seu percurso não foi efetivada devido às dificuldades de suprimentos aos trabalhadores - isolamento de algumas áreas. O trecho que logrou sucesso com a Transbrasiliana, neste contexto, conectava Anápolis à Colônia Agrícola Nacional de Goiás (CANG), implantada em 1941 no Vale do São Patrício, na região Centro Goiana. A CANG, nomeada em 1953 de Ceres, é uma cidade nova de caráter agrícola, que dispunha, em Anápolis, de um ramal ferroviário para a distribuição de seus produtos para a região Sudeste do país. Goiás, interessado nesta política de ocupação/interiorização, criou a Colônia Agrícola Estadual de Rubiataba, em 1948, na gestão do engenheiro e então governador Jerônymo Coimbra Bueno 4 (LIMA, 2012). Localizada próxima à CANG e à Transbrasiliana - para desfrutar do potencial logístico desta infraestrutura -, Rubiataba foi pensada e implantada para ser uma cidade rural de Goiás - estimada para 10 mil habitantes -, dispondo de desenho urbano semelhante ao desenvolvido pela Construtora Coimbra Bueno \& Cia Ltda. à cidade de Luiziânia, no interior do estado de São Paulo. Neste interim, cerca de 400 quilômetros da Transbrasiliana haviam sido construídos em Goiás.

Antes da política de promoção de Infraestruturas de Transporte do Governo Kubitschek, em específico, a da rodovia Belém-Brasília, algumas experiências institucionais prévias nos auxiliam no debate aqui exposto. A criação da $\mathrm{Su}-$ perintendência do Plano de Valorização
Econômica da Amazônia (SPVEA) em 1953 teve um papel de destaque nas políticas posteriormente adotadas. Essa Superintendência foi criada para realizar um plano efetivo de promoção de transportes e comunicação na Amazônia, bem como estabelecer bases econômicas e técnicas para sua execução (Lei no 1.806, de 06 de janeiro de 1953). Sua Comissão de Planejamento chega, em 1954, a um diagnóstico sobre as dificuldades de exploração e intervenção neste bioma: 1) faltava investimentos e recursos; 2) longas distâncias das áreas ocupadas que dificultavam o suprimento material para as obras. A causa da não continuidade da execução da Transbrasiliana durante os governos Dutra (1946-1951) e Vargas (1951-1954) coincide amplamente com aquelas apontadas pela Comissão. Conforme Michele Sousa e Rafael Pacheco (2013, p. 254), além das iniciativas da Era Vargas, em 1948 o deputado federal Jales Machado da Siqueira havia contribuído com sua implantação até Jaraguá e com seu planejamento até Porto Nacional, no norte de Goiás. A proposta deste deputado era de que esta ligação seria estabelecida por um complexo multimodal com a ligação rodo-férreo-fluvial Anápolis-Belém.

$\mathrm{Na}$ gestão de Kubitschek, no ano de 1957, avançavam-se os estudos para irrupção da Floresta Amazônica, pois em novembro, a abertura da estrada já alcançava a latitude de Porto Nacional, atualmente no estado de Tocantins, à época, na região Norte de Goiás (cerca de $700 \mathrm{~km}$ do canteiro de obras de
${ }^{4}$ Jerônymo Coimbra Bueno, juntamente com seu irmão Abelardo Coimbra Bueno, ambos formados em Engenharia Civil na Escola Politécnica do Rio de Janeiro entre os anos de 1929 e 1933, fundaram a firma Coimbra Bueno \& Penna Chaves Ltda., junto com o colega Roberto Penna Chaves, com foco em construção e urbanismo. Em 1934, assumiram a direção geral das obras de Goiânia. Mais tarde, a firma se tornou apenas Coimbra Bueno e Cia. Ltda. 
Brasília). Em maio de 1958 foi criada a Comissão Executiva da Rodovia Belém-Brasília (Rodobrás), subordinada à SPVEA, cuja estratégia foi delimitada da seguinte maneira: era necessário, para que a rodovia fosse concluída em tempo hábil e adequado ao cronograma da inauguração de Brasília, que duas frentes trabalhassem em simultaneidade e em direções opostas, uma sentido Norte-Sul, outra, sentido Sul-Norte. O engenheiro agrônomo Bernardo Sayão, coordenador da Rodobrás, ficou responsável pela frente Sul-Norte e o médico sanitarista Waldir Bouhid pela frente Norte-Sul (KUBITSCHEK, 2000). Assim, foram acrescentados aos 400 quilômetros da Transbrasiliana cerca de $1.500 \mathrm{~km}$, infraestrutura que viria a ter, em 1959, quando inaugurada, $1.966 \mathrm{~km}$.

Diferentemente das cidades de origem espontânea houve uma forte iniciativa de criação de cidades novas nas proximidades desta infraestrutura que rasga o Brasil de Brasília a Belém. A intenção de ocupá-la estava vinculada a um processo econômico estratégico de manutenção das obras e suporte aos desbravadores da mata virgem do Cerrado e da Amazônia, mas não somente. Havia, mesmo que preliminarmente, uma expectativa de implantação de áreas agriculturáveis e de criação de animais com a finalidade de estabelecer, a partir de seus núcleos urbanos, bases para a configuração de economias que garantissem o futuro desenvolvimento de seus territórios. Tal ação concretizaria não somente a implementação da rodovia
Belém-Brasília, mas ofertaria suporte aos futuros viajantes que dela desfrutassem. Esta medida foi estimulada pelos desbravadores e contou, inclusive, com a contribuição de topógrafos, agrimensores e engenheiros no planejamento e execução de planos urbanísticos. Imperatriz, no Maranhão, coloca-se como um caso exemplar, visto que seu prefeito Raimundo de Morais Bastos (1959-1960) contou com o auxílio de técnicos da Rodobrás para solucionar o problema da expansão do pequeno núcleo urbano da cidade e para sua demarcação e implantação.

Em suma, as cidades ali construídas teriam papel fundamental na ocupação da nova configuração do território centro-norte do país, e a elas caberiam a implantação e controle da produção, bem como no comércio de seus insumos. Têm-se, por exemplo, os casos de Alexânia (1957) e Abadiânia (1960-61), em Goiás; Araguaína (1958), Gurupi (1958), Miranorte (1959) e Colinas do Tocantins (1960), no atual estado do Tocantins; Açailândia (1958), Imperatriz (1959) e Itinga do Maranhão (1959), no Maranhão; e Ulianópolis (1958), no Pará (Figura 1).

Todas elas cidades novas criadas durante o governo de Juscelino Kubitschek e sob sua influência direta, durante a implantação e euforia nacional da transferência da capital para Brasília. O tamanho, ainda que acanhado de alguns desses novos núcleos urbanos, indica a expectativa de ocupação lenta em função do pretenso isolamento. Todavia, casos como Gurupi, no Tocantins, e Imperatriz, 


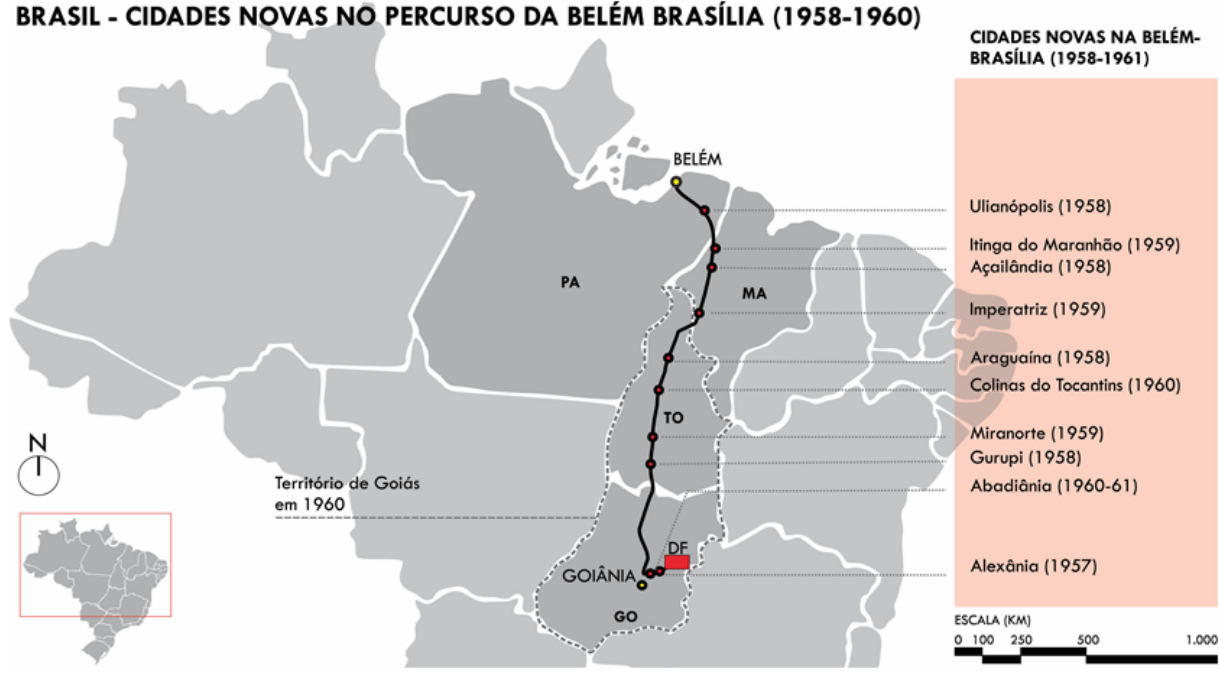

no Maranhão, revelam a superação de tal preceito, as quais rapidamente apresentaram altos índices de crescimento, tanto populacional quanto econômico. Ainda que seus desenhos sejam derivados de uma malha ortogonal com ruas e quadras de dimensões regulares - uma técnica antiga perpetuada por milênios quando da solução mais racional e econômica para a implantação de uma nova cidade -, no mínimo, o valor de tais cidades pertence a uma tradição, não somente brasileira, mas ocidental de construir e intervir sobre território. Ademais, não obstante a estes casos citados, as áreas portuárias de Belém (PA) e São Luís (MA) lograram importantes benefícios após a conclusão da infraestrutura, muito em função da modernização da produção e do papel de escoamento da produção desempenhado por tais cidades.

Estes casos são exemplos do impacto imediato da criação de Brasília, aqui averiguado em uma leitura da curta duração de sua transferência. A própria Belém-Brasília e a capilaridade no território por ela possibilitado revela o valor de sua capacidade integradora, fator fundamental para o amadurecimento da economia nacional desde então. Neste sentido, é importante salientar este processo de implantação de novas cidades não foi diretamente criado a partir de decretos do executivo nacional, mas por ele estimulado, ora de forma direta como veremos a partir dos objetos em foco neste documento -, ora somente pela relevância do Plano Piloto de Brasília e das transformações na estrutura e conjuntura nacional. Em função disso afirmamos que uma leitura encerrada no Plano Piloto de Brasília pode incorrer em equívocos teóricos e conceituais. Ressaltamos que o tão criticado isolamento do centro do país só poderia ser resolvido com sua ocupação.
Figura 1 - Localização das cidades novas ao longo da rodovia Belém-Brasília criadas durante o governo de Juscelino Kubitschek. Fonte: Autor, 2018. 


\section{DE OLHOS D'ÁGUA A ALEXÂNIA}

Alexânia é uma cidade nova de relocação, em que sua antiga sede foi transferida de sítio. A abordagem de suas particularidades, inevitavelmente, tocará alguns pontos da história política do protagonista de sua criação, Alex Abdallah. Este político emprestou seu nome à cidade que fundou, estipulando assim uma auto-homenagem concreta, material, fato que lhe dispensa uma estátua, condecorações ou seu nome em qualquer rua ou bairro. Tal fato já nos revela sua força política, sua relevância para o contexto local e de certo modo regional, visto as alianças posteriores por ele firmadas. A construção da presente narrativa se deu pela leitura e análise da trama urbana, por entrevistas e mapeamentos, bem como pela consulta à escassa bibliografia, a qual nos emprestou datas, nomes e características importantes do projeto e do processo de formação da nova cidade, visto que o projeto original ou suas cópias encontram-se desaparecidas.

Olhos D'Água é um pequeno distrito, hoje pertencente a Alexânia, que já foi a sede do município por duas vezes. Surgiu como um aglomerado em 1940, quando foi erguida uma capela a Santo Antônio e uma escola. A rápida construção de casas no derredor da capela fez com que em 1954 ela fosse elevada a Distrito de Corumbá de Goiás, à época, cidade mais próxima. A relação de seus moradores com Corumbá, na maioria camponeses, era estreita. O saber popular sobre as construções da antiga cidade colonial, em técnicas e tecnologias, foi incorporado pelos mestre-de-obras e pedreiros do pequeno Distrito, fato que fez sua paisagem se assemelhar sobremaneira à da sede do município. Anacronismos à parte, um cenário da cultura popular e sertaneja se firma largamente em Olhos D'Água. As economias, manufatureira e agrícola, surgiram com a cidade. $\mathrm{O}$ cultivo de produtos como o feijão, o arroz, o milho, o café, a mandioca, o algodão e a cana-de-açúcar; a produção de seus derivados como o melaço, a rapadura, a farinha e o queijo; a produção manufatureira de tecidos e malhas, bem como de vasos de barro e peças de madeira entalhada, garantiam a autossuficiência do Distrito e suas relações comerciais com Corumbá de Goiás (LIMA, 1995).

Em 1958, Olhos D’Água foi elevada à categoria de Município, mesmo ano em que sua sede foi transferida para Alexânia. Alex Abdallah, de origem sírio-libanesa, era seu prefeito. À espera de que Juscelino cumprisse sua Meta Síntese, dois anos antes, em 1956, Abdallah iniciava sua busca por terrenos próximos ao futuro Distrito Federal. Com as demarcações do percurso da rodovia Brasília-Anápolis, em 1957, três fazendas dela lindeiras, que se encontravam em uma planície, foram negociadas e compradas. Abdallah julgou que este terreno, sem grandes declives e aclives, era adequado para a realização de seu plano. Segundo Ricardo Lima (1995), este processo ocorreu silenciosamente, cuja maioria dos moradores de Olhos D’Água desconhecia as reais intenções do político. 
Alex Abdallah era o novo dono das três glebas que formavam 30 alqueires de campo. Neste interim inicia-se as visitas a cidades-referência, como Jaraguá, Diolândia, Uruana e Ceres, todas em Goiás. Seu objetivo inicial era que Alexânia fosse, assim como Ceres, uma cidade rural (CURADO, 2015). Segundo o Edital de Loteamento de 20 de março de 1957, registrado no Cartório de Registro de Imóveis da cidade de Corumbá de Goiás, e publicado no jornal "O Corumbaense Goiano" em 10 de abril do mesmo ano, Abdallah contratou o projeto para a nova cidade da Empresa Brasil de Imóveis Limitada, de Belo Horizonte (MG). Neste documento a grafia do nome da cidade era "Alex-ânia", com especificação para ser uma Cidade Industrial, diferentemente de suas intenções iniciais. A justificativa para tal decisão, informa-nos Ramir Curado (2015), era de que Abdallah não possuía recursos para implanta-la, direcionando Alexânia à abertura para negociação com empresários e industriais, cuja proximidade com Brasilia lhes seria um potente atrativo. Em entrevista a Guilherme Verano, Alex Abdallah (2012) afirma que era próximo a Pedro Ludovico Teixeira - antigo governador de Goiás, responsável pela mudança da capital-, e que se inspirou em suas ações mudancistas para planejar Alexânia. Ao narrar sua epopeia afirma:

Realmente hoje, olhando a priori, olhando para trás, com o advento de Brasília o meu grande lucro foi justamente [ter] ocupado uma porção do sertão inóspito de meu estado e criado condições de vida para centenas e milhares de famílias. [...] O meu sonho não era atender ao vislumbre do poeta e não passar a vida em brancas nuvens, mas deixar as nossas marcas por aqui através de pelo menos uma árvore plantada. Eu queria plantar muito mais do que uma árvore, eu queria plantar uma floresta de casas. Consegui. (ABDALLAH, 2012)

O desenho urbano de Alexânia origina-se a partir de uma preocupação com sua articulação regional. A rodovia Brasilia-Anápolis cruza sentido leste-oeste o terreno destinado ao novo perímetro urbano. Na cumeeira do sítio sentido Noroeste uma via de conexão regional foi estabelecida para articular a nova cidade a Olhos D'Agua e Corumbá de Goiás. Ali, nos limites do perímetro foi determinada a criação de um aeroporto para pequenas aeronaves, públicas e particulares. Para o estabelecimento do Setor Central, três fatores foram preponderantes: o estabelecimento de uma especialização de vias, uma estreita proximidade com a rodovia e a delimitação da área mais aplanada do terreno.

A especialização de vias foi garantida pelas seguintes decisões: 1 ) as quadras lindeiras à rodovia teriam perfil comercial e de serviços privados; 2 ) a via perpendicular à Rodovia (sentido norte-sul) - Avenida 15 de Novembro, com caixa viária de 15 metros - teria uma sequência de 20 quadras de $55 \mathrm{~m} \times 55 \mathrm{~m}$ destinadas aos edifícios dos poderes administrativo e legislativo, bem como a espaços 


\section{DIRETRIZES INICIAIS DO PROJETO URBANO DA CIDADE DE ALEXÂNIA}

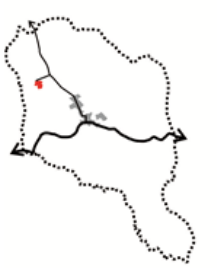
PERÍMETRO URBANO E MUNICIPAL
EM 1958

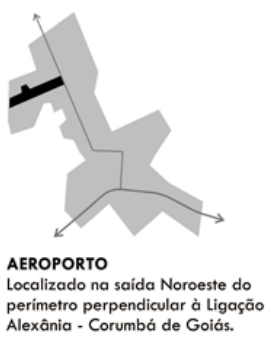
princípios e diretrizes iniciais para o estabelecimento do núcleo central da nova cidade. Fonte: Autor, 2018. perímetro perpendicular à Ligaçấa

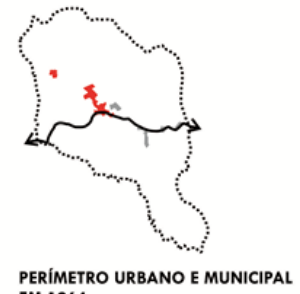

PERIMETRR
EM 1964

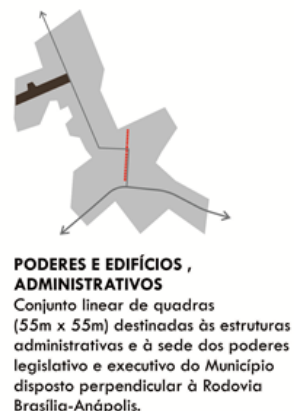
disposto perpen
Brasilia-Anápolis.

públicos; e 3) outra via - atual Avenida Nelson Santos (também sentido norte-sul) - seria a grande chegada da cidade, portando, assim, uma caixa viária de 40 metros, com um largo canteiro central que abrigaria edifícios para os serviços e equipamentos públicos (Figura 2). Diferentemente do conjunto de quadras destinado aos poderes públicos, o corredor de serviços públicos cruza a Rodovia, ficando parte dele ao norte e parte ao sul. A parte norte contém a Biblioteca Pública, o Posto de Saúde, o Fórum e a Secretaria Municipal de Educação (antigo Departamento Municipal de Educação e Cultura -DEMEC). Ao sul ficaria a Feira e o Mercado públicos. A Avenida Nelson Santos delineia o caráter de "entrada principal", pois é a única via, em toda a malha deste Setor, que estabelece uma hierarquia viária clara, reforçada
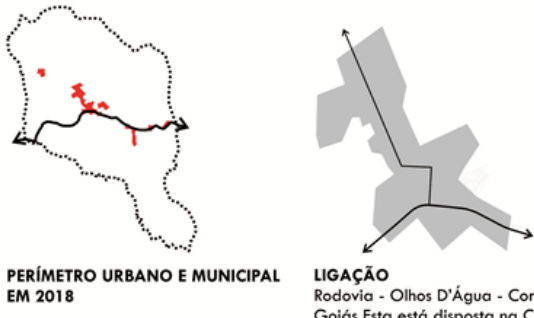

UGACÃo Rodovia - Olhos D'Água - Corumbá de Goiás Esta está disposta na Cumeeira
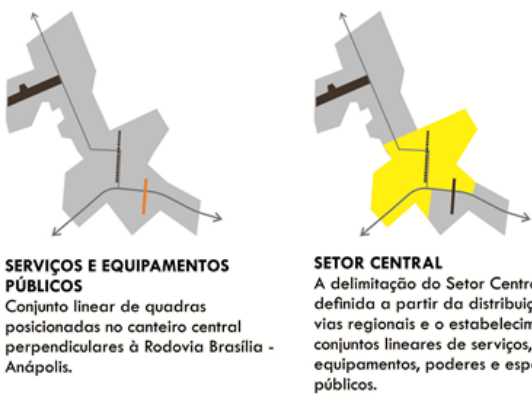

SETOR CENTRAL A delimitação do Setor Central foi definida a partir da distribuiçäo das vias regionals $e$ o estabelecimento equipamentos, poderes e espaços públicos. pela presença, lindeira a ela, da Rodoviária. Diante destas decisões, delimitou-se o Setor Central estritamente vinculado à rodovia. A Igreja Matriz, que ocupa uma quadra no centro deste Setor (Quadra 70), domina a paisagem da cidade e orienta sua leitura e deslocamentos. No plano de Alexânia há uma coerência na distribuição de quadras e avenidas em relação ao Setor Central, pois manteve-se na implantação e na consequente ocupação o dimensionamento original.

O estabelecimento de um macrozoneamento foi feito a partir da criação de setores (Figura 3). Além do delineamento do Setor Central, no limite noroeste, próximo ao aeroporto, foi pensada uma ocupação de baixa densidade e de uso predominantemente residencial, assemelhando-se a uma espécie de subúrbio-jardim. Nas avenidas, usos mistos eram permitidos, 


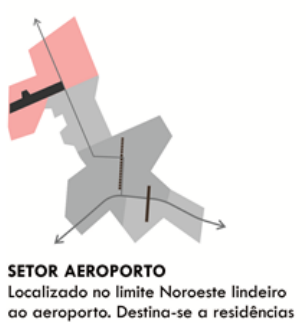
ao aeroporto. Desting-se a residências e pequenas indústria

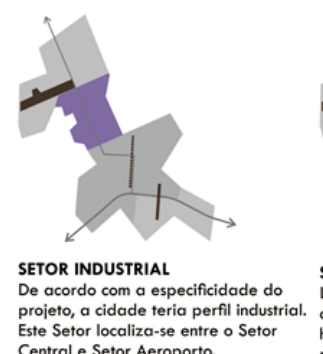

Este Setor localiza-se entre Central e Setor Aeroporto.

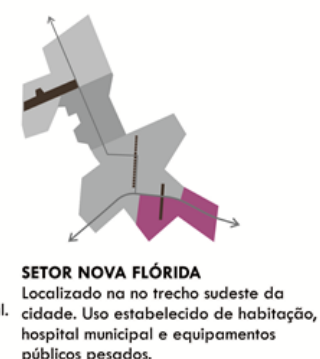

hospital municipal
públicos pesados.

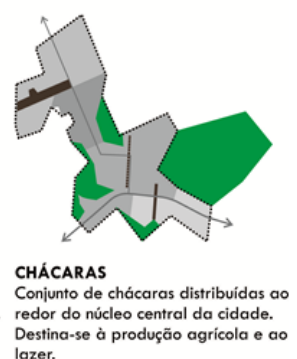
Destina se
lazer. mas com a conservação de uma paisagem predominantemente horizontal, cuja finalidade era respeitar as demandas das eventuais operações aeroportuárias. Este seria o Setor Aeroporto - assemelhando-se ao projeto inicial de Goiânia e seu Setor Aeroporto, cujo desenho, inclusive, lhe guarda semelhanças. Entre o Setor Aeroporto e o Setor Central foi delimitado o Setor Industrial, composto por lotes maiores, mas com pouca variação no dimensionamento das quadras. Nele seria permitido maiores índices de ocupação dos lotes, contando inclusive com afastamentos maiores e proporcionais às ocupações. Na região limítrofe entre o Setor Central e o Setor Industrial foi localizado o cemitério municipal, cuja posição revela o horizonte ocidental da paisagem rural do município. Voltando à rodovia, a parte oeste do seu perímetro, sentido Anápolis, pertence ao Setor Central. A parte leste, sentido Brasília, refere-se ao Setor Nova Flórida, responsável por abrigar o hospital municipal, hotéis e pousadas, cargas e descargas de caminhões bem como, na continuidade da Avenida Nelson Santos, a presença da Feira e do Mercado. Há uma grande quantidade de chácaras neste
Setor, muitas delas anteriores ao início da implantação da cidade. Em função dessa presença e abundância de água no local, ali se estabeleceu um parcelamento de chácaras - assim como nos limites dos Setores Central e Industrial -, inclusive a algumas delas foi destinado o uso de lazer urbano. Nova Flórida foi o primeiro nome dado popularmente às ocupações iniciais e, segundo Abdallah (2012), foi o primeiro nome dado à cidade, no entanto, sem registro.

Neste sentido, assim como coloca $\mathrm{Ra}-$ mir Curado (2015, p. 74), “[...] a planta original de Alexânia privilegiava áreas para o lazer, áreas para estacionamento de veículos, áreas comerciais, área para um aeroporto, entre outras". Tal complexidade, ainda distante da realidade da maioria dos municípios goianos, fez insurgir uma narrativa de modernidade em Alexânia, já presente em Goiânia, Anápolis, Aragarças e Brasília (LACERDA; TREVISAN, 2018). Tal processo se deu pela racionalidade de sua malha viária (Figura 4) bem como a utilização de técnicas de planejamento urbano modernas como a setorização, o zoneamento e a especialização de vias.
Figura 3 - Estabelecimento do zoneamento e dos setores da cidade de Alexânia. Fonte: Autor, 2018. 
Pedro Henrique Máximo Pereira RicARDo TREVISAN
Figura 4-Malha viária e quadras do projeto urbanístico para Alexânia. Fonte: Autor, 2018.

Figura 5-a) Colocação da pedra fundamental do município, em 1957, próximo à rodovia Brasília-Anápolis; b) Demarcação de vias da nova trama urbana no cerrado, em 1957. Fonte: Alex Abdallah, 2012.

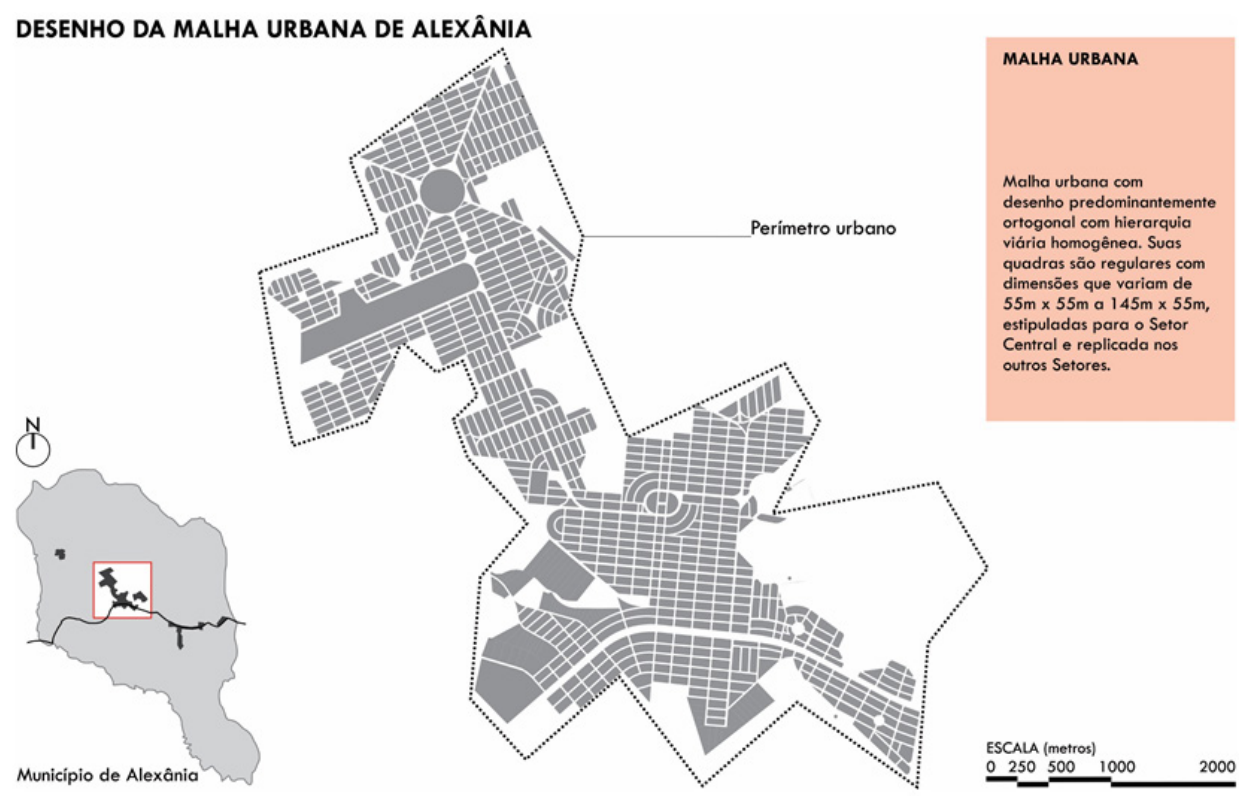

A ocupação inicial da cidade ocorreu que a cidade fosse implantada de acordo com as especificações presentes no projeto, Abdallah contou com trabalhadores de Olhos D’Água, Corumbá de Goiás e Anápolis. Além do mais, para a coordenação das obras, Fritz Gezets, um engenheiro alemão residente em Goiânia, foi contratado. Segundo Paula Stumpf (2014), a mudança da sede do município foi encarada pelos moradores de Olhos D’Água como um golpe a seu desenvolvimento, visto que os investimentos e a
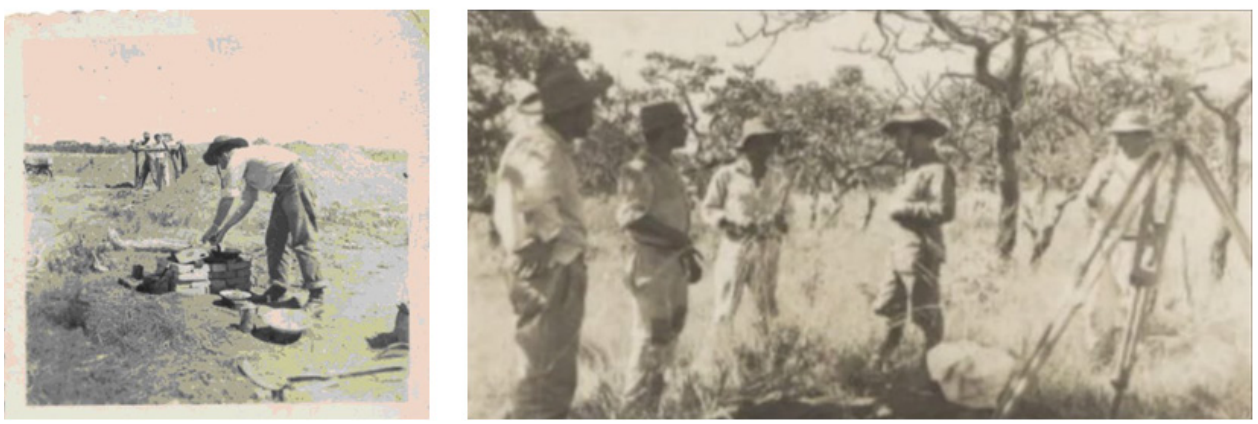
disponibilidade de energia elétrica (neste momento produzida por um gerador) direcionavam-se a Alexânia.

O trecho de Alexânia limítrofe à rodovia foi, no projeto, pensado para que ela fizesse parte da paisagem urbana. Sua ocupação ocorreu, de certo modo, acelerada nos anos iniciais (Figura 6a); no entanto de modo desigual em toda a malha implantada. O comércio lindeiro à rodovia era pujante (Figura 6b), bem como sua arquitetura inicial tinha traços do racionalismo carioca, como no Clube Nova Florida, de 1965 (Figura 6c). Não obstante, o nome da cidade, mesmo com a mudança da sede do município, permaneceu Olhos D’Água até 1963. Conflitos eram frequentes visto que havia forte resistência à iniciativa de Abdallah, fato que atrasou as negociações e, de certo modo, contou com relações mais estreitas com Anápolis e Brasília do que com sua antiga sede.

\section{DE POSSE D'ABADIA A ABADIÂNIA}

Seguindo a lógica das cidades de relocação, o caso de Abadiânia também colabora para a narrativa de implantação deste conjunto de cidades novas no interior do Brasil. A história de Abadiânia é marcada por uma sucessão de conflitos territoriais, ora latentes, ora evidentes. As marcas deste processo estão presentes em seu espaço urbano. Os dois principais nomes que representam as forças deste conflito são Oribes Gontijo (ex-prefeito) da Silva e Osorio Rodrigues Camargo (ex-vereador). Este dado foi testificado a partir de fontes primárias (plantas urbanísticas, memorial descritivo, documentos de cartório) e pela entrevista com filhos destes dois protagonistas, Ronaldo Gontijo (ex-prefeito do município) e Irene $\mathrm{Ca}$ margo. Cabe, antes de adentrarmos aos meandros dessa história, uma observação: o que entendemos aqui por conflito refere-se a uma característica intrínseca à logica dos territórios como fronteiras. Portanto, no caso de Abadiânia, este conflito é locacional, fenômeno que se revela materialmente na divisão física da cidade por meio da infraestrutura que a fez surgir: a rodovia.

Abadiânia foi o novo nome dado ao antigo povoado de Corumbá de Goiás, Posse, quando da sua elevação a Distrito
Figura 6 - a) Alexânia em 1976; b) Posto de combustível Texaco à beira da rodovia; c) Clube Nova Flórida, de $1965-$ traços da arquitetura racionalista carioca. Fonte: Revista Alexânia Ontem-Hoje, novembro de 1976.

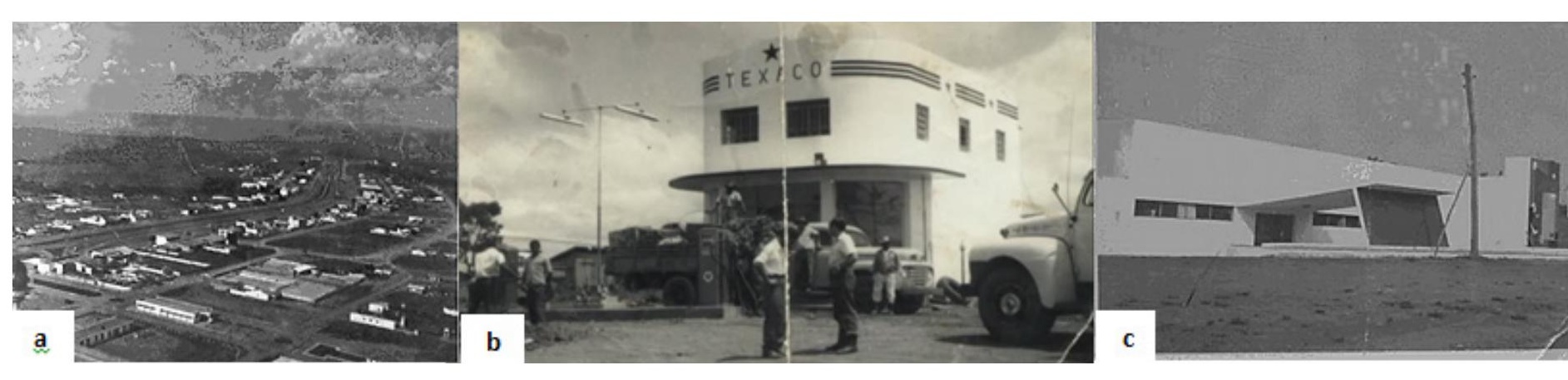


em 1943 e emancipada em 1954. Este nome está ligado à ancestralidade deste pequeno núcleo, formado pela lenta migração de devotos à Nossa Senhora da Abadia e pela relevante peregrinação de fieis ao local, rito cuja gênese remonta a meados do século 19 e que permanece

5 José Espíndola era um almirante da Marinha Brasileira, também um importante radiotelegrafista. Segundo Irene Camargo (2017), este militar, conhecido como Dr. Espíndola, prestou socorro à sua mãe que passava por uma depressão pós-parto na ocasião de uma de suas visitas a Lindo Horizonte (Abadiânia). até nossos dias (GOMES DA SILVA, 2005). Seu traçado urbano, relativamente regular, não seria empecilho para sua expansão caso sua localização não fosse num vale, assim como as coloniais Goiás e Pirenópolis. Com o anúncio da construção de Brasília e das infraestruturas necessárias para interligá-1a às regiões após as eleições de 1955 , inicia-se as visitas técnicas para demarcação do percurso da rodovia Brasília-Anápolis. A notícia da mudança do local da sede de Abadiânia começa a se alastrar em 1956 quando o engenheiro Bernardo Sayão visitou o pequeno núcleo religioso e se encontrou com autoridades locais, segundo Reinaldo Gontijo (2017). Essas visitas à região, conforme Irene Camargo (2017), passaram a ser regulares, não somente por Sayão, mas por José Espíndola ${ }^{5}$ e pelo próprio Presidente Juscelino Kubitschek e sua equipe.

Na planície em que hoje se localiza a rodovia, nas imediações da nova cidade, havia uma estrada que eventualmente era utilizada para pousos e decolagens aéreas, da comitiva responsável por demarcar o percurso da rodovia. Nas imediações desta estrada havia as instalações de Osório Rodrigues Camargo, um importante cerealista e proprietário das fazendas Capivari e Soledad. Nelas encontrava-se um bar, uma pousada e um comércio de secos e molhados, lugar muito utilizado pelos viajantes. Com as obras da rodovia iniciadas, as instalações da Construtora Rabello S.A., de Minas Gerais, atraíram trabalhadores que começaram a se fixar no loteamento feito por Osório de $\mathrm{Ca}$ margo, no limite norte da rodovia. Este loteamento composto por 14 quadras recebeu o nome de Lindo Horizonte, inspirado na relação que Osório tinha com Belo Horizonte. Nele foi instalada a primeira escola da região que possuía por nome "Reunidos de Lindo Horizonte".

Do outro lado da rodovia, na parte sul, encontrava-se as instalações da NOVACAP que, mesmo depois da inauguração da infraestrutura, permaneceu em Abadiânia para sua manutenção e para o plantio das extensas áreas de eucalipto, presentes até hoje nos horizontes da cidade (CAMARGO, 2017). Em 1960, Juscelino Kubitschek, ao passar pelas instalações da NOVACAP deixou um telegrama a Oribes com os seguintes escritos: "Oribes Gontijo da Silva, mude a cidade para o Planalto Central, pois, Brasilia é uma realidade". Seguindo as orientações do então Presidente da República, Oribes dá andamento à mudança de sítio da cidade e enviou o projeto de Lei $\mathrm{n}^{\circ} 11$ à Câmara Municipal, sendo aprovada em 3 de agosto de 1960. A escolha do sítio já estava préselecionada, visto que nas imediações da Rodovia já existia as ocupações de Lindo Horizonte. A Fazenda Soledad foi escolhida, pois ela revelava-se uma planície adequada à instalação da futura sede 
CONDICIONANTES LOCAIS PARA O PROJETO DE ABADIÂNIA
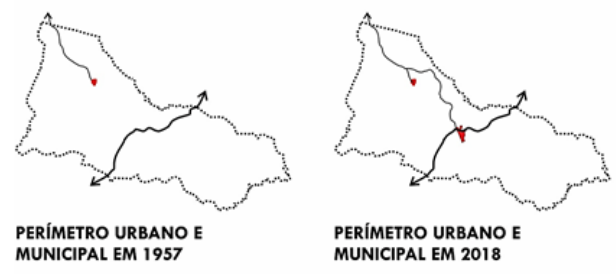

do município (Figura 7). Aqui há um conflito de fontes. Irene Camargo (2017) afirma que a fazenda foi doada ao município. Ronaldo Gontijo (2017) afirma que ela foi desapropriada pelo município. Segundo dados presentes no Livro 3B de Transcrições das Transmissões de 10 de maio de 1961, presente no Cartório do $1^{\circ}$ Ofício de Notas e Registro de Imóveis de Abadiânia, houve uma desapropriação com pagamento de 255 mil cruzeiros por 25 alqueires de campo.

O projeto e o início das obras datam também de 1961. O projeto foi encomendado a Nilton Rabello (CREA. C.p.296.), um agrimensor que, segundo Gontijo (2017), trabalhava na região de Corumbá de Goiás. ${ }^{6}$ O projeto apresenta uma solução erudita, comum em projetos relevantes na história do urbanismo: o patté d'oie ou a pata de ganso, repertório utilizado por Attilio Corrêa Lima no projeto de Goiânia (1932-1935), capital do estado. Oribes Gontijo era próximo de Pedro Ludovico Teixeira e o admirava, assim como Alex Abdallah. A referência máxima para o prefeito, neste sentido, seria a capital. Com visitas in loco a Goiânia e esboços, Rabello decidiu apresentar um
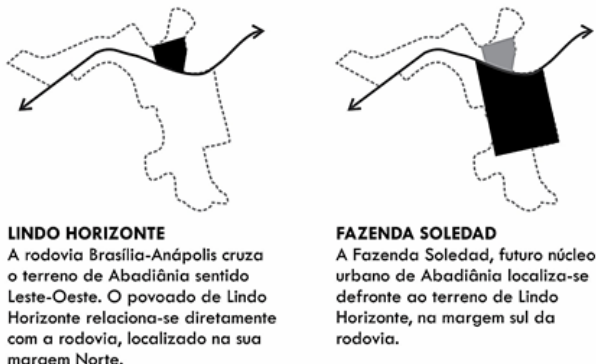

FAZENDA SOLEDAD A Fazenda Soledad, futuro núcleo urbano de Abadiânia localiza-se defronte ao terreno de Lindo Horizonte, na margem sul da partido urbanístico com fortes semelhanças ao de Corrêa Lima. Além do traçado, a setorização da cidade e a locação dos edifícios públicos guardavam esta relação. A convergência das vias culminava na Praça Cívica, por nome Praça D'Abadia. Margeando a Praça estariam os edifícios públicos, como a Prefeitura, o Fórum, os Bancos e a Agência dos Correios, bem como a Igreja Matriz e um Cinema. O plano ainda conta com mais duas quadras margeadas pelas diagonais, a Avenida Anápolis (sentido noroeste) e a Avenida Brasília (sentido nordeste). Uma Delegacia foi pensada e localizada na porção sul do plano. As áreas comunitárias como o Setor de Lazer, o Ginásio, o Mercado Público e o Estádio Municipal também ficaram nos limites sul da cidade, bem como uma Escola, afastados da rodovia (Figura 8).

O plano tende à simetria, mas ela não foi plenamente conquistada em função do desenho da rodovia. A chegada mais fluida à cidade seria pela rodovia no sentido Anápolis-Brasília (oeste), ponto mais distante da Praça Cívica, dado que fez com que um deslocamento da via, no plano, já fosse desenhado. A avenida que
Figura 7 - Principais condicionantes locais para elaboração do projeto urbanístico de Abadiânia. Fonte: Autor, 2018.

\footnotetext{
${ }^{6}$ Pela descrição física e de comportamento de Nilton Rabello feita por Reinaldo Gontijo (2017), presume-se que este agrimensor trabalhava para a Construtora Rabello, responsável por desbravar o trecho da Brasília-Anápolis que passava pelo território de Abadiânia.
} 
Figura 8 - Diretrizes estabelecidas no plano urbanístico de Abadiânia. Fonte: Autor, 2018
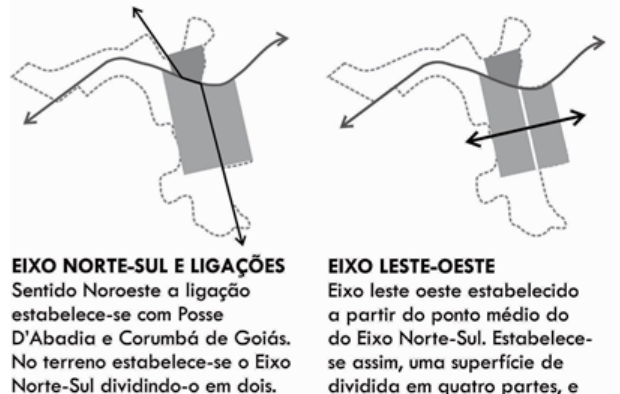

EIXO LESTE-OESTE Eixo leste oeste estabelecido a partir do ponto médio do do Eixo Norte-Sul. Estabelecese assim, uma superficie de dividida em quatro partes, e um ponto central.

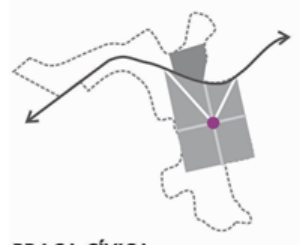

PRAÇA CÍVICA

Ponto central de convergêncio das Diagonais e dos Eixos, estabelece-se a Praça Cívica Municipal, com serviços públicos e administrativos em sua face Sul e de Lazer e Culto, ao Norte.

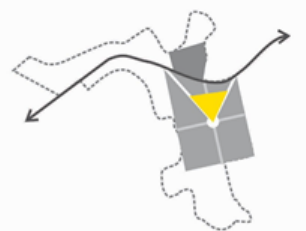

TRIÂNGULO SAGRADO Na Praça Civica destina-se um terreno à Matriz. No ponto Médio das diagonais mais dois terrenos são destinados à lgrejo. Estes formam um Triângulo Sagrado cujos vértices são Igrejas.

cruzaria a cidade de Norte a Sul teria o nome de Abadiânia, fazendo referência à antiga sede de município. Tal fato ocorre em função das perspectivas que a cidade implantada teria por nome Altamira (concorrendo com o nome do loteamento vizinho, Lindo Horizonte). Contudo, o nome de Altamira foi impossibilitado pelos trâmites de mesma natureza no estado do Pará, com uma cidade homônima, permanecendo assim Abadiânia (Figura 9).

A implantação da cidade, ao sul da rodovia, também foi acompanhada por Nilton Rabello. Com a execução dos primeiros lotes, aqueles lindeiros à rodovia, a ocupação da cidade intensifica-se neste trecho, concorrendo também com Lindo
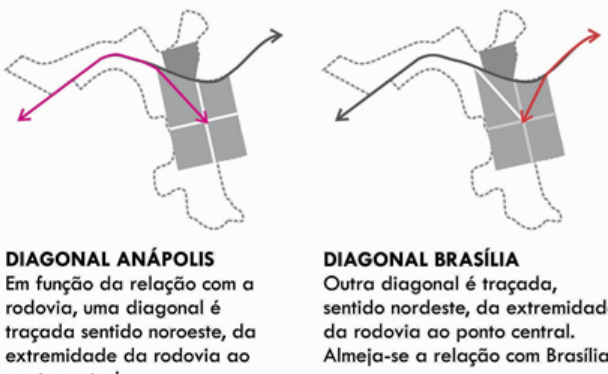

DIAGONAL BRASÍLIA Outra diagonal é traçada, sentido nordeste, da extremidade Ameja-se a relação com Brasilta. xtremidade da rodovia ao ponto central.

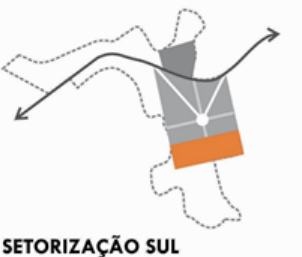

Além do estabelecimento dos usos erganização macro da cidade, na faixa Sul da cidade localiza-se os setores de Lazer, Esportes Educação.

Horizonte e as ocupações da Fazenda Capivari, ao norte. É importante salientar que as preexistências lindeiras ao plano de Altamira (Abadiânia), não são reveladas nos desenhos, mas são indicadas por nomes e são descritas tanto por Irene Camargo (2017) quanto por Ronaldo Gontijo (2017). Neste sentido, a rodovia, objeto que parecia unificar as forças políticas no projeto de transferência da sede de Abadiânia, neste contexto pós-1960 transforma-se em uma clara fronteira de disputas territoriais. $\mathrm{Na}$ parte norte da rodovia, em razão de ter sido o núcleo inicial e preexistente, tem-se a falta de conteúdos técnicos, como a transição de bairros ou loteamentos novos, bem como um desenho urbano 


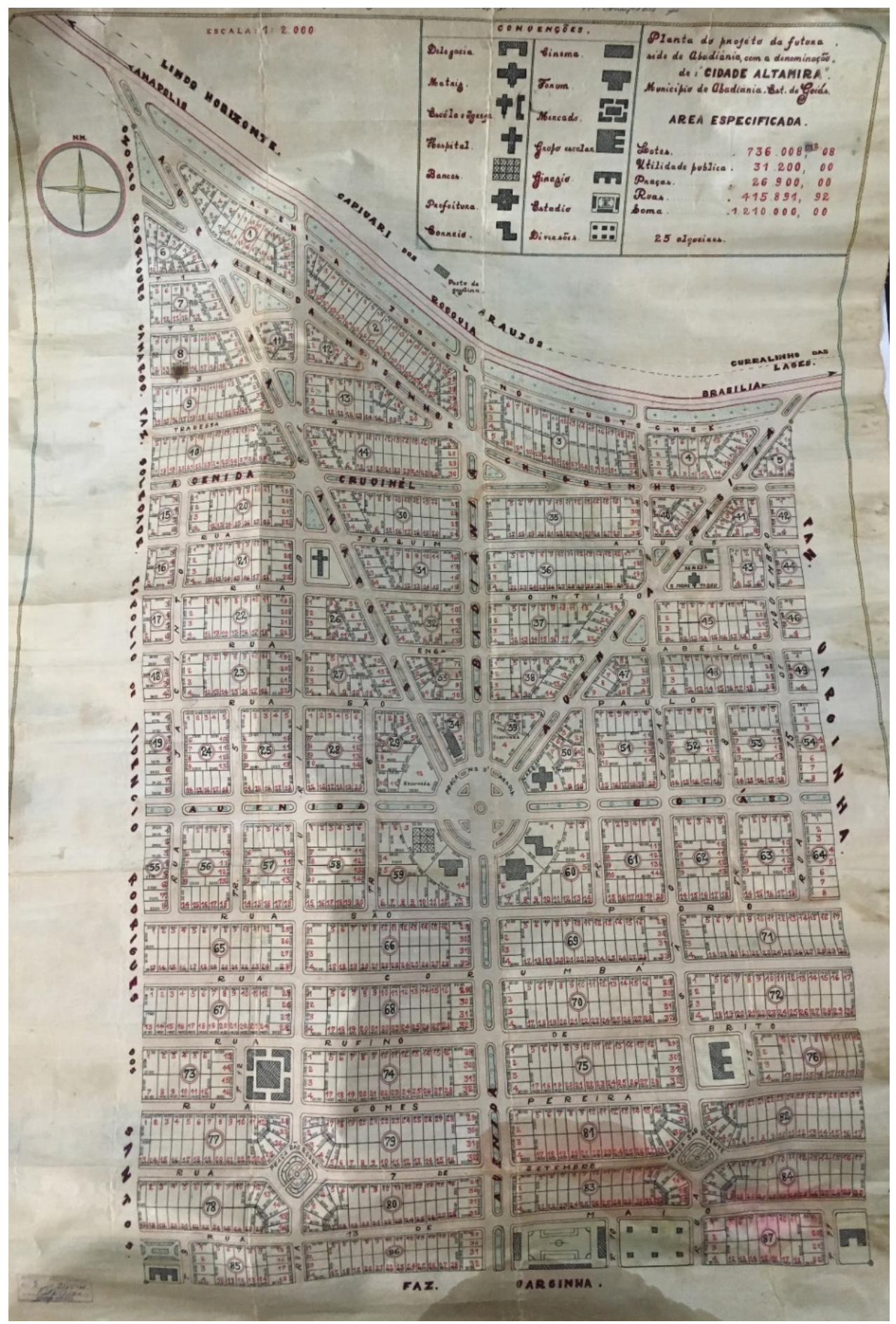

Figura 9 - Planta original da cidade de Altamira, atual Abadiânia, de 1961. Fonte: Cartório do $1^{\circ}$ Ofício de Notas e Registro de Imóveis de Abadiânia, 2018. 
pouco fluido, diferentemente do caso da nova cidade pensada e implantada ao sul. O projeto de Nilton Rabello, em totalidade, representa um conjunto urbanístico que, de certo modo, equaciona problemas de circulação com uma hierarquia viária adequada ao sítio e à relação com a rodovia, além de uma setorização relativamente clara.

A luta, não pela posse da terra, mas pela sua ocupação por terceiros se acirra entre as partes norte e sul da rodovia. A disponibilidade de lotes na porção sul da rodovia, no núcleo planejado, bem como sua extensão, fez com que as negociações fossem facilitadas. Ali, as primeiras ocupações ocorreram pela expressiva doação de lotes, fato que induziu à posterior comercialização dos que estavam ainda disponíveis. Dada esta urbanização inicial, com população estimada em 3 mil habitantes (IBGE, 2017), os poderes foram transferidos para a nova sede em 1963 pela Lei Municipal no 67 de 12 de setembro. A disputa por atração de moradores se encerra quando Osorio Camargo falece em 1965, ficando o núcleo preexistente com estagnação de crescimento nas próximas três décadas, período em que o novo núcleo implantado ao sul teve maior expressão de crescimento e ocupação. Tal processo se altera quando, em 1998, João Teixeira de Faria (João de Deus), que havia chegado à cidade em 1976 e se instalado próximo à Praça Cívica, muda-se para os limites norte do município, nos rincões da Fazenda Capivari, na Vila Bastos. A Casa Dom Inácio de Loyola, que neste contexto ascende internacionalmente com suas práticas religiosas, inverte a lógica de valorização dos terrenos de Abadiânia e de seu crescimento urbano. O novo núcleo implantado, ao sul, perde força e desvaloriza-se em detrimento das aceleradas ocupações e valorização do solo urbano ao norte da rodovia, que conta com aproximadamente cinquenta pousadas vinculadas ao turismo religioso. Para além deste processo, que é recente, o valor e Abadiânia para a construção de um vocabulário urbanístico no Brasil Central junta-se, com este trabalho, aos demais casos já pesquisados, em pesquisa, e aqueles que serão ainda descobertos e revelados.

\section{CONCLUSÃO}

Seria possível medir ou averiguar os impactos territoriais da transferência da capital federal do Rio de Janeiro para Brasília? Iniciamos este documento com esta inquietação, angústia motivada pelos recentes ataques à cidade, à interiorização dos poderes e ao processo dela derivado. Diferente do que possa parecer, este documento não é, a priori, uma defesa de seus autores, personagens políticos ou de seu famoso projeto. Cientes de que este esforço já foi intensamente dispendido por importantes pesquisadores e intelectuais ao longo de sua juventude, nos debruçamos para além desta seara e posicionamos Brasília por outro viés: existiriam Brasílias fora de Brasília ou distantes dela? $\mathrm{O}$ que gerou a nova 
capital na dimensão urbana do interior da nação?

Brasília, em suas esferas estética e política, extrapolou a si própria. Sua criação e implantação fez revelar lugares do Brasil outrora desconhecidos e inóspitos, e hoje, suportes para culturas eminentemente urbanas e ávidos ao fortalecimento de suas economias regionais e locais. Para chegar a tais conclusões estabelecemos dois recortes: a leitura aqui encampada referiu-se à curta duração da criação e implantação da nova capital (1956-1960) e ao longo trecho da rodovia Belém-Brasília (1958-1959). Neste recorte espaço-temporal, verificamos que a transferência da capital federal para a hinterlândia desdobrou-se em políticas locais e iniciativas privadas de criação de novas cidades, ou seja, as políticas adotadas na escala federal reproduziram-se nas microescalas das políticas regionais e locais tocadas pela Belém-Brasília. Diretamente influenciados por Brasília, dez casos de cidades novas foram identificados: Alexânia (1957) e Abadiânia (1960-61), em Goiás; Araguaína (1958), Gurupi (1958), Miranorte (1959) e Colinas do Tocantins (1960), no atual estado do Tocantins; Açailândia (1958), Imperatriz (1959) e Itinga do Maranhão (1959), no Maranhão; e Ulianópolis (1958), no Pará.

Destes casos, Alexânia e Abadiânia foram escolhidos para serem explanados e aprofundados. Além de serem cidades novas de relocação, a criação de ambas as cidades foi diretamente influenciada por Juscelino Kubitschek durante a constru- ção da Anápolis-Brasília (1957-1958), um trecho da Belém-Brasília. Ademais destes importantes fatos, vislumbramos que este documento acrescente estas cidades nas discussões futuras sobre as cidades novas no Brasil, visto que as informações aqui apresentadas sobre seus projetos e processos de implantação são inéditas na historiografia.

Nelas, o rebatimento do Plano Piloto de Brasília aparecem das seguintes maneiras: 1) ambas situam-se em planícies, sendo este o principal critério adotado para a escolha do lugar para implanta-las; 2) ambas possuem projeto, sendo o de Alexânia derivado de uma malha ortogonal com especialização de vias e zoneamento, e Abadiânia derivado do repertório da patté d'oie (pata de ganso), com hierarquia viária clara e setorização; 3) ambas foram projetadas por profissionais: Alexânia por técnicos da Empresa Brasil de Imóveis Limitada, de Belo Horizonte, e implantada pelo engenheiro alemão Fritz Gezets, e Abadiânia, projetada e implantada pelo agrimensor Nilton Rabello, que trabalhava em Corumbá de Goiás; 4) ambas satisfazem ao desejo de políticos locais e federais de mudança de seus antigos sítios para o Planalto Central, respondendo à eminente necessidade (5) de ocupa-lo. Por fim, 6) ambas representam seu tempo, assim como Brasilia, de uma modernidade particularmente progressista, desenvolvimentista e nacionalista, que no contexto de suas criações utilizaram-se do repertório e do vocabulário do urbanismo moderno para se materializarem. 
A implantação da rodovia foi imprescindível para que estas cidades fossem criadas e conectadas entre si. Ela foi uma espécie de fio condutor dos fluxos ao interior e a partir dele, e fio aglutinador de ocupações e de experiências urbanísticas que culminou na modernização das cidades preexistentes e na criação de novas. Com recorte em Alexânia e Abadiânia, a leitura também deve considerar o importante papel exercido por Anápolis e Goiânia neste contexto, cidades mais desenvolvidas e ocupadas na região até então. Em conjunto com Anápolis, essas duas cidades novas auxiliaram na construção de Brasília e da Brasília metropolitana com o fornecimento de tijolos e telhas (em função de forte indústria cerâmica que nelas estão instaladas), bem como de areia e pedras (disponível em abundância às margens do Rio Corumbá). Neste sentido, configurou-se desde a implantação da Anápolis-Brasília (1957-1958), da Belém-Brasília (19581959) e destas novas cidades uma rede urbana relativamente ocupada capaz de subsidiar a formação da região urbana Goiânia-Brasília no alvorecer do século 21. No mais, a depender da escala a se averiguar as transformações no interior do Brasil no recorte pós-1960, será inescapável enxergar Brasília, mesmo que ela não seja o alvo das questões. $\mathrm{O}$ valor da nova capital, mais do que ela própria, está na modernização dos rincões do país e na nova vida que ela propiciou, mesmo estando a aproximadamente 2.000 quilômetros de distância dela.

\section{REFERÊNCIAS}

ABDALLAH, Alex. Alex Abdallah. [2012] Entrevista concedida a Guilherme Verano, 2012.

CAMARGO, Irene. Como Abadiânia nasceu? depoimento. [17 de julho, 2017]. Entrevista concedida a Pedro Henrique Máximo Pereira, 2017.

CHAIA, Vera; CHAIA, Miguel Wady. A dimensão política de Brasília. Cadernos Metrópole (PUCSP), v. 20, p. 165-178, 2008.

COSTA, Lucio. Relatório do Plano Piloto de Brasília. Brasília: GDF, 1991.

COUTO, Ronaldo Costa. Brasília Kubitschek de Oliveira. Rio de Janeiro: RECORD, 2001.

CURADO, Ramir. Alexânia, a cidade dos meus sonhos: a saga de Alex Abdallah, o fundador de Alexânia. Corumbá de Goiás: edição do autor, 2015.

GOMES DA SILVA, Célio. A história de Oribes: exemplo de responsabilidade fiscal. Goiânia: São José Gráfica e Editora, 2005.

GONTIJO, Ronaldo. Como Abadiânia nasceu? depoimento. [17 de julho, 2017]. Entrevista concedida a Pedro Henrique Máximo Pereira, 2017.

HOLSTON, James. Cidade Modernista: uma crítica de Brasília e sua utopia. São Paulo: COMPANHIA DAS LETRAS, 1993. 
KUBITSCHEK, Juscelino. Por que construi Brasília. Brasília: SENADO FEDERAL, CONSELHO EDITORIAL, 2000.

LACERDA, Larissa Alves; TREVISAN, Ricardo. Aragarças no Brasil Central: modernidades pré-Brasília. In: ANAIS do V Enanparq, Salvador, 15-19 de outubro de 2018.

LIMA, Cassimiro da Mata. Rubiataba: Primeiros tempos 1948-1959. Goiânia: KELPS, 2012.

LIMA, Ricardo Gomes (Org.). Fios de Olhos D'Água. Rio de Janeiro: FUNARTE, CFCP, 1995.

SOUSA, Michelle Louise, PACHECO, Rafael Araújo. A Influência da Rodovia Belém-Brasília no Processo de Desenvolvimento das Cidades do Centro-Norte de Goiás. Revista Geoaraguaia, v. 3, p. 246-262, 2013.

STUMPF, Paula Groehs Pfrimer Oliveira. Sertões e Patrimônios: uma história de Santo Antônio de Olhos D’Água-GO. In: Patrimônio e História. LEAL, Elisabete; PAIVA, Odair da Cruz (Orgs.). Londrina: UNIFIL, 2014.

TREVISAN, Ricardo. Cidades Novas. Tese de doutoramento. Brasília: FAU-UnB, 2009.

Pedro Henrique Máximo Pereira - Arquiteto e Urbanista (UEG), Artista Visual (UFG), mestre em Arquitetura e Urbanismo pelo PPG-FAU-UnB e doutorando pelo mesmo programa. É professor dos cursos de Arquitetura e Urbanismo da UEG e PUC-Goiás, e participa dos grupos de pesquisa Paisagem, Projeto e Planejamento LABEURBE (UnB), Novas Cidades (UnB) e Cronologia do Pensamento Urbanístico (UFBA).E-mail: arqurb.phmp@gmail.com

Ricardo Trevisan - Arquiteto e Urbanista (IAU-USP), mestre em Engenharia Urbana (UFSCar) e doutor em Arquitetura e Urbanismo (UnB). É professor dos cursos de graduação e pós-graduação em Arquitetura e Urbanismo da FAU-UnB. É líder do grupo de pesquisa Paisagem, Projeto e Planejamento - LABEURBE (UnB), e coordenador do grupo Cronologia do Pensamento Urbanístico na UnB. E-mail: prof. trevisan@gmail.com 